\title{
Safety and Efficacy of Ankaferd Hemostat (ABS) in the Chemotherapy-Induced Oral Mucositis
}

\author{
M. Hilmi ATAY ${ }^{1}$, Nevin A. ASLAN ${ }^{1}$, Sude AKTIMUR ${ }^{1}$, Piltan BUYUKKAYA ${ }^{1}$, Engin KELKITLI ${ }^{1}$, \\ Mehmet TURGUT ${ }^{1}$, Ibrahim HAZNEDAROGLU ${ }^{2}$ \\ ${ }^{1}$ Ondokuz Mayıs Universty, Faculty of Medicine, Department of Hematology, Samsun \\ ${ }^{2}$ Hacettepe üniversity, Faculty of Medicine, Department of Hematology, Anakara, TURKEY
}

\begin{abstract}
Oral mucositis, characterized by ulcerative lesions in the oral mucosa of patients undergoing chemotherapy, is currently considered to be the most severe complication of anti-cancer therapy which is affecting $40-80 \%$ of those patients. Ankaferd hemostat, (ABS) is the first topical hemostatic agent regarding the red blood cell (RBC)-fibrinogen interactions tested in the clinical trials. ABS also has pleiotropic effects particularly in the tissue healing and has anti-infective properties. The aim of this study is to assess the safety and efficacy of ABS in the management of chemotherapy-induced oral mucositis in adult patients with hematological malignancies. ABS was topically applied to the patients with grade 3-4 mucositis according to the WHO classification. Patients were said to mouthwash and swallow the five milliliters of ABS. Twenty patients with oral mucositis were evaluated. Eleven patients with acute myeloid leukemia, four acute lymphoblastic leukemia, three non-hodgkin lymphoma, one hemophagocytosis with acute myleoid leukemia and one hemophagocytosis were included in study. Median extract amount was calculated as $74.50 \mathrm{ml}(30-100 \mathrm{ml})$ and median healing time was 6.6 days (3-10). Consequently, ABS is an effective agent in the treatment of chemotherapy related severe oral mucositis in patients with hematological malignancies. Further experimental and clinical trials about ABS shall focus on the interrelationships between proteomic content, fibrinogen gamma, and vital erythroid aggregation due to ABS.
\end{abstract}

Keywords: Oral mucositis, Chemotherapy, ABS, Tissue healing

\section{ÖZET}

\section{Kemoterapiye Bağı Gelişen Oral Mukozitte Ankaferd Hemostatın (ABS) Güvenliği ve Etkinliği}

Kemoterapi alan hastaların oral mukozasında ülseratif lezyonlar ile karakterize olan oral mukozit, hastaların \% 40-80 kadarında görülmekte olup günümüzde kanser tedavisinin en şiddetli komplikasyonu olduğu düşünülmektedir. Ankaferd hemostat (ABS), klinik deneylerde test edilmiş, kırmızı kan hücresi (RBC) -fibrinogen etkileşimleri ile ilgili olan ilk topikal hemostatik ajandır. ABS'nin özellikle doku iyileşmesi üzerinde pleiotropik etkileri olduğu gibi enfeksiyona karşı koruyucu özellikleri de vardır. Bu çalışmanın amacı, hematolojik malignitesi olan erişkin hastalarda kemoterapi kaynaklı oral mukozit tedavisinde ABS'nin güvenilirliğini ve etkinliğini değerlendirmektir. ABS, Dünya Sağlık Örgütü sınıflamasına göre evre 3-4 mukoziti olan hastalara topikal olarak uygulandı. Hastalara beş mililitre ABS’yi, garagara yaparak yutması söylenildi. Oral mukoziti olan yirmi hasta değerlendirildi. Çalışmaya alınan on bir hastada akut myeloid lösemi, dört hastada akut lenfoblastik lösemi, üç hastada non-hodgkin lenfoma, bir hastada akut myeloid lösemi ve hemofagositoz ve bir hastada hemofagositoz tanıları mevcuttu. Ortalama kullanılan ABS solusyon miktarı $74.50 \mathrm{ml}$ (30-100 ml) ve ortalama iyileşme süresi 6.6 (3-10) gün olarak bulundu. Sonuç olarak ABS, hematolojik malignitesi olan hastalarda kemoterapiye bağlı ciddi oral mukozit gelişmesi durumunda tedavide etkin bir ajandır. ABS ile ilgili gelecek deneysel ve klinik çalışmalar proteomik içerik, fibrinojen gamma ve ABS'ye bağı vital eritroid agregasyon arasındaki ilişkilere odaklanmalıdır.

Anahtar Kelimeler: Oral mukozit, Kemoterapi, ABS, Doku iyileşmesi 


\section{INTRODUCTION}

Oral mucosa is affected from chemotherapeutics easily because of its' high cell-turnover. Oral mucositis, characterized by ulcerative lesions in the mucosa of patients undergoing chemotherapy, is currently considered to be the most severe complication of anti-cancer therapy. It is affecting 40$80 \%$ of patients who are receiving chemotherapy. ${ }^{1}$ Clinical aggressiveness of oral mucositis can affect the nutritional status, proper chemotherapy administration and quality of life of the affected patients. ${ }^{2}$

ABS is the first topical hemostatic agent regarding the red blood cell (RBC)-fibrinogen interactions tested in the clinical trials. ${ }^{3}$ ABS is composed of standardized plant extracts including Alpinia officinarum, Glycyrrhiza glabra, Thymus vulgaris, Urtica dioica and Vitis vinifera. ABS induced pharmacological modulation of essential erythroid proteins (ankyrin, spectrin, actin) can cause vital erythroid aggregation via acting on fibrinogen gamma. ABS has pleiotropic effects particularly in the tissue healing and has also anti-infective properties. $^{3-5}$

In spite of being one of the most investigated subjects among supportive care in chemotheraphy patients, none of the treatment alternatives has been found effective in the treatment of chemotherapyinduced oral mucositis. The aim of this study is to assess the safety and efficacy of ABS in the management of chemotherapy-induced oral mucositis in adult patients with hematological malignancies. To evaluate the role of topical ABS application in the management of oral mucositis is highly important for the underlying malign disease prognosis because the untreated severe ulcers may lead to temporary or permanent treatment interruption which can complicate the underlying malignant disease control and treatment. ${ }^{1}$

\section{PATIENTS AND METHODS}

Twenty patients with oral mucositis of grade 3-4 according to the WHO classification (Table 1). After chemotherapy between the dates of $1 / 10 / 2012$ $01 / 11 / 2014$ in the hematology service of Ondokuz Mayıs University Hospital, were included in this study. ${ }^{6}$ All of these patients were taking protec-

\begin{tabular}{|ll|}
\hline Table 1. WHO Oral Mucositis Grading Scale \\
\hline Grade & Description \\
\hline O (none) & None \\
I (mild) & Oral soreness, erythema \\
II (moderate) & Oral erythema, ulcers, solid diet \\
III (severe) & tolerated \\
IV (life-threatening) & Oral ulcers, liquid diet only \\
\hline
\end{tabular}

tive chlorhexidine gluconate mouthwash since the chemotheraphy initiation. Only after patients developed oral mucositis they used only Ankaferd. Age and gender of patients, type of the underlying malignant disease and used chemotherapeutic drugs, frequency, amount and duration of ABS use and healing time of oral mucositis were recorded. The study protocol was approved by the Ethics Committee of Ondokuz Mayıs University (OMU KAEK No: 2015/233).

\section{Statistical Analysis}

All statistical analyses were conducted with the SPSS statistical package for Windows version 15.0 (SPSS Inc., Chicago, IL, USA). All continuous variables were shown by mean \pm SD. Intergroup comparison of the non-parametric data was used Mann-Whitney U test. $\mathrm{P}<0.05$ was considered statistically significant.

\section{RESULTS}

Twenty patients with oral mucositis ( 8 male and 12 female) were evaluated. Median age of the patients was 43.6 (19-60) years. The underlying malignant diseases were: acute myeloid leukemia (11 patients), acute lymphoblastic leukemia (4 patients), non-Hodgkin lymphoma (3 patients), hemophagocytosis with acute myleoid leukemia (1 patient) and hemophagocytosis (1 patient). Eleven patients had used ABS twice in a day, five patients had used ABS three times in a day and four patients had used ABS four times in a day. The amount of used ABS was $30 \mathrm{ml}$ in four patients, $50 \mathrm{ml}$ in three patients, 


\begin{tabular}{|c|c|c|c|c|c|c|c|}
\hline No & $\begin{array}{l}\text { Age/ } \\
\text { years }\end{array}$ & Sex & $\begin{array}{l}\text { Type of } \\
\text { disease }\end{array}$ & $\begin{array}{l}\text { Chemotherapy } \\
\text { regimens }\end{array}$ & $\begin{array}{l}\text { Frequency } \\
\text { of ABS }\end{array}$ & $\begin{array}{l}\text { Volume of } \\
\text { ABS } / \mathrm{ml}\end{array}$ & $\begin{array}{l}\text { Mucositis } \\
\text { recovery } \\
\text { time/days }\end{array}$ \\
\hline 1 & 52 & $F$ & AML & Ida+ Ara-c & q8h & 100 & 7 \\
\hline 2 & 49 & $\mathrm{~F}$ & AML & Flu+Ara-c & bid & 100 & 10 \\
\hline 3 & 60 & M & Lymphoma & HD-mtx+Ara-c & bid & 50 & 10 \\
\hline 4 & 19 & M & ALL & Mtx+Ara-c & bid & 50 & 5 \\
\hline 5 & 43 & $F$ & AML & Idarubisin & bid & 100 & 10 \\
\hline 6 & 28 & $\mathrm{~F}$ & Lymphoma & HD-mtx+ Ara-c & bid & 100 & 10 \\
\hline 7 & 27 & $\mathrm{~F}$ & Lymphoma & $\begin{array}{l}\text { HD-mtx+ } \\
\text { gemcitabine }\end{array}$ & bid & 100 & 10 \\
\hline 8 & 70 & M & Hemophagocytosis & Etoposide & bid & 50 & 7 \\
\hline 9 & 23 & M & ALL & HD-mtx +Ara-c & q8h & 30 & 3 \\
\hline \multirow[t]{2}{*}{10} & 31 & M & $\mathrm{AML}+$ & HD-Ara-C+ & q8h & 100 & 7 \\
\hline & & & Hemophagocytosis & Etoposide & & & \\
\hline 11 & 47 & M & AML & Azacitidine & bid & 30 & 3 \\
\hline 12 & 19 & M & ALL & $\mathrm{Mtx}+\mathrm{MCP}$ & bid & 80 & 10 \\
\hline 13 & 53 & F & AML & Ida+Ara-c & q6h & 80 & 4 \\
\hline 14 & 57 & $F$ & AML & HD Ara-c & q8h & 100 & 5 \\
\hline 15 & 49 & $F$ & AML & Ida+ Ara-c & bid & 60 & 4 \\
\hline 16 & 48 & $F$ & AML & HD-Ara-c & bid & 30 & 3 \\
\hline 17 & 28 & $\mathrm{~F}$ & AML & Flu+ Ara-c & q8h & 100 & 3 \\
\hline 18 & 58 & $\mathrm{~F}$ & AML & Flu+ Ara-c & q6h & 100 & 7 \\
\hline 19 & 58 & M & AML & Ida+ Ara-c & q6h & 80 & 6 \\
\hline 20 & 53 & $F$ & ALL & $M t x+$ Ara-c & q6h & 30 & 3 \\
\hline
\end{tabular}

$60 \mathrm{ml}$ in one patient and $100 \mathrm{ml}$ in nine patients. Median extract amount was calculated as 74.50 $\mathrm{ml}(30-100 \mathrm{ml})$ and median healing time was 6,6 days (3-10 days). Except for the temporary metalic taste, no adverse effect was observed in patients. Characteristics of patients and used chemotherapeutics and ABS treatments are shown in Table 2.

Patients were divided into two groups according to the total drug dose as high and low. High doses of medication intake was associated with a prolonged recovery time. It is interpreted as a reasonable result because with the increase in severity of oral mucositis, drug dose and recovery time are also needed to be increased. The small number of the study group and lack of a control group may have influenced our statistical results.

\section{DISCUSSION}

Next-generation RBC-related hemostatics, such as ABS nanohemostat, was designed for the essential treatment of life-threatening bleedings by acting on RBCs and restoring physiological hemostasis. ${ }^{7}$ Prohemostatic and antithrombin activi- 
ties of ABS are linked to fibrinogen gamma chain and prothrombin by functional proteomic analyses. Those unique hemostatic properties of ABS provide a balanced hemostasis representing a basis for physiological wound healing. ${ }^{8}$ The proteomics of the structural and functional properties of the proteins, that related to the wound healing, should also be matched with the already established proteomics of ABS. ${ }^{9}$ Randomised clinical trials (RCT) showed the safety and efficacy of ABS for the control of clinical hemorrhages in a wide variety of settings. ${ }^{10,11}$ However, there is no RCT related to wound healing effect of ABS.

Experimental trials showed that ABS is effective in wound healing process. Aktaş et. al. has also demonstrated that applying ABS after tooth extraction resulted as increased secretion of some factors which has roles in early phase of wound healing. These factors were collagen type 1, collagen type 3 , smooth muscle actin, fibronectin, beta 2 microglobulin, vascular endothelial growth factor and cyclooxygenase- 2 . As a result, with the help of these mechanisms, ABS provide rapid wound healing. ${ }^{12}$ Moreover, ABS can cause polymorph nuclear leukocyte and mono-nuclear leukocyte infiltrations, vascularisation and fibroblast proliferation in mucosal tissue which can also have a role in facilitating the wound healing. ${ }^{13}$ Kaya et al. found that topically used ABS decreased the wound diameter and inflammation grade and also increased the tissue fibrosis and wound contraction on the burned wounds. ${ }^{14}$

Bacteria and fungi can be isolated from blood and oral cavity cultures in some patients with oral mucositis. The most common bacteria that were isolated from cultures are Gram negative bacteria, aerobes and fungi (Candida albicans). ${ }^{15}$ There are in vitro studies which has showed antibacterial and antifungal activity of ABS. ${ }^{16,17}$ When ABS is added to the culture medium, it inhibits colonies of Acinetobacter, Escherichia coli and Pseudomonas species growth. ${ }^{18}$

Numerous treatment protocols and preventing methods had been tested on the patients with oral mucositis. ${ }^{19}$ There is only one drug which is containing palifermin, was approved by the Food and Drug Administration (FDA) in the USA for the pre- vention of oral mucositis. Palifermin is a recombinant human keratinocyte growth factor (KGF) derivative. This drug was approved for patients with hematological malignancy undergoing high-dose chemotherapy followed by stem cell transplantation. However side effects such as pain, arthralgia and dysaesthesia were reported. ${ }^{20}$ Other studies including allopurinol, chlorhexidine and hydrogen peroxide did not show any benefit of those drugs in mucositis treatment. ${ }^{21,22}$ Maltodextrin, sodium hyaluronidase, alcohol and gelclair which is containing anesthetic are used because of their mucosal barrier properties. But gelclair did not have any shown superiority compared to the other drugs. ${ }^{23}$ There is limited number of studies in the literature about prevention and treatment of oral mucositis with herbal medicine. In those studies decrease in the oral mucositis with the use of those herbal medicines have already been reported but no information was given about the healing time. ${ }^{24,25,26}$ In a study by Abdulrhman M, and et al. honey and a mixture of honey, beeswax, and olive oil-propolis extract was used in pediatric group of grade 2-3 oral mukositis patients, healing time was found to be shorter. ${ }^{27}$

UK Oral Mucositis in Cancer Group give some suggestions for grade 3-4 mucositis patients:

1) If there is pain use powerful analgesics (such as morphine sulphate and oxycodone), if those are ineffective fentanyl pathches can be used, 2) If there is a decrease in oral feeding, intravenous or enteral feeding support should be considered, 3) 4-10 times a day oral Caphosol solution (calcium and phosphate ions) should be used. Mouthwash with gelclair (a coating protectant) is needed before each meal, 4) Mouthwash with diluted tranexamic acid should be done 4-6 times a day if there is bleeding, 5) If there is fungal infection, use anti-fungal agent (such as fluconazole and posaconazole). If there is viral infection, use anti-viral agent such as acyclovir. If there is bacterial infection, use anti-bacterial antibiotics.

There are few publications which reported the activity of ABS on chemotherapy related oral mucositis. The first one was a case report about a patient with refractory AML whose haemorrhagic oral mucositis had been recovered in two days with ABS application. ${ }^{28} \mathrm{~A}$ recent clinical study by 


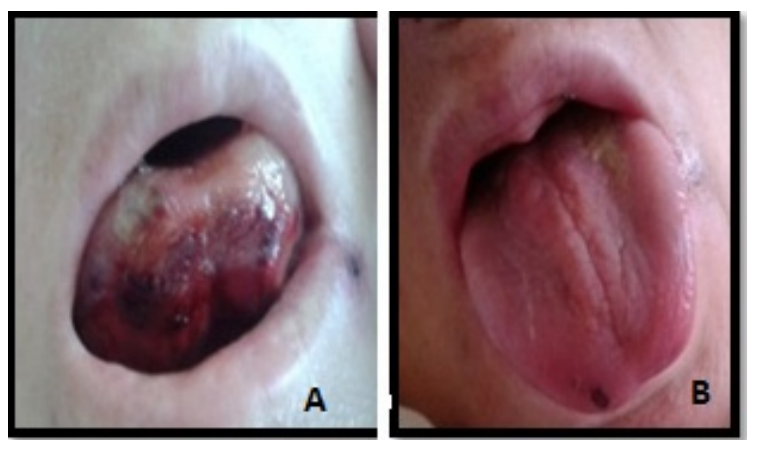

Figure 1A. Oral mucositis of the patient after induction regimen for acute myeloid leukemia. 1B. After using ancaferd blood stoper mucositis was healed.

Patıroglu et al. has demonstrated that topical ABS application at the beginning of the chemotherapy was provided less oral mucositis when compared to the control group. ${ }^{29}$

Chemotherapy-related oral mucositis may develop within 7-10 days after the end of the chemotherapy. Complete recovery is seen in about two weeks. ${ }^{11} \mathrm{In}$ this study, with the use of ABS, the median healing time was 6.6 days. Therefore, the healing duration of oral mucositis was shorter than the other agents with the topical ABS application. And also the hemorrhages from oral mucositis lesions were recovered within two days with the application of ABS (Figure 1A and B). Therefore, its hemostatic efficacy is an important benefit, in addition to its antibacterial and wound healing properties. There are two limitations in this study. First one is the lack of control group for the comparison of these findings. Second one is the diversity of diseases of the patients participating the study and treatment differences may have influenced the results of this study

\section{Conclusion}

ABS is an effective agent in the chemotherapy related severe oral mucositis treatment of the patients with hematological malignancies. ABS shortens the healing time with acceptable side effects. It is the first study that shows effectiveness of ABS application in chemotherapy related oral mucositis in adult patients. We hope that further trials that emphasize the importance of ABS use in the management of chemotherapy related oral mucositis will take place and also includes the interrelationships between proteomic content, fibrinogen gamma, and vital erythroid aggregation due to ABS.

\section{REFERENCES}

1. Campos MI, Campos CN, Aarestrup FM, Aarestrup BJ. Oral mucositis in cancer treatment: Natural history, prevention and treatment. Mol Clin Oncol 2: 337-340, 2014.

2. Karthaus M, Rosenthal C, Ganser A. Prophylaxis and treatment of chemo and radiotherapyinduced oral mucositis - are there new strategies? Bone Marrow Transplant 24: 1095-108, 1999.

3. Haznedaroglu BZ, Beyazit Y, Walker SL, Haznedaroglu IC. Pleiotropic cellular, hemostatic, and biological actions of Ankaferd hemostat. Crit Rev Oncol Hematol 83: 21-34, 2012.

4. Tasdelen Fisgin N, Tanriverdi Cayci Y, et al. Antimicrobial activity of plant extract Ankaferd Blood Stopper. Fitoterapia 80:4850, 2009.

5. Isler SC, Demircan S, Çakarer S, et al. Effects of folk medicinal plant extract Ankaferd Blood Stopper on early bone healing. J Appl Oral Sci 18: 409-14,2010.

6. Sonis ST, Elting LS, Keefe D. Perspectives on cancer therapyinduced mucosal injury: pathogenesis, measurement, epidemiology, and consequences for patients. Cancer 1: 100(9 Suppl): 1995-2025, 2004.

7. Huri E, Beyazit Y, Mammadov R, et al. Generation of Chimeric "ABS Nanohemostat" Complex and Comparing Its Histomorphological In Vivo Effects to the Traditional Ankaferd Hemostat in Controlled Experimental Partial Nephrectomy Model. Int $\mathrm{J}$ Biomater 4: 949-460, 2013

8. Ozel-Demiralp D, Igci N, Ayhan B, et al. Prohemostatic and antithrombin activities of Ankaferd hemostat are linked to fibrinogen gamma chain and prothrombin by functional proteomic analyses. Clin Appl Thromb Hemost 18: 604-610, 2012.

9. Demiralp DO, Haznedaroglu IC, Akar N. Functional Proteomics of Ankaferd Blood Stopper. Turk J Hematol 27: 70-77, 2010.

10. Teker AM, Korkut AY, Gedikli O, Kahya V. Prospective, controlled clinical trial of Ankaferd Blood Stopper in children undergoing tonsillectomy. Int J Pediatr Otorhinolaryngol 73: 17421745, 2009.

11. Teker AM, Korkut AY, Kahya V, et al. Prospective, randomized, controlled clinical trial of Ankaferd Blood Stopper in patients with acute anterior epistaxis. Eur Arch Otorhinolaryngol 267: 1377-1381, 2010.

12. Aktas A, Er N, Korkusuz P, et al. Ankaferd-Induced Early Wound Healing of Soft Tissue in an Experimental Rat Model. Turkiye Klinikleri J Med Sci 31: 185-195, 2012.

13. Akalin C, Kuru S, Barlas AM, et al. Beneficial effects of Ankaferd Blood Stopper on dermal wound healing: An experimental study. Int Wound J 10: 1742-48, 2012.

UHOD Number: 3 Volume: 25 Year: 2015 
14. Kaya H, Gokdemir MT, Sogut O, et al. Effects of folk medicinal plant extract ankaferd blood stopper on burn wound healing Acta Med Mediterranea 29: 497-502, 2013

15. Anirudhan D, Bakhshi S, Xess I, et al. Etiology and Outcome of Oral mucosal lesions in Children on Chemotherapy for Acute Lymphoblastic Leukemia. Indian Pediatrics 45: 47-51, 2008.

16. Akkoc N, Akcelik M, Haznedaroglu $\mathrm{H}$, et al. In vitro Anti-Bacterial Activities of Ankaferd Blood Stopper. Int J Lab Hematol 30: 95, 2008.

17. Akkoc N, Akcelik M, Haznedaroglu IH, et al. In Vitro Antibacterial Activities of Ankaferd Medicinal Plant Extract. Turkiye Klinikleri J Med Sci 29: 410-415, 2009.

18. Saribas Z, Sener B, Haznedaroglu IC, et al. Antimicrobial activity of Ankaferd Blood Stopper ${ }^{\circledR}$ against nosocomial bacterial pathogens. Central Eur J Med 5: 198-20, 2010.

19. Pico JL, Avila Garavito A, Naccache P. Mucositis: its occurrence, consequences, and treatment in the oncology setting. Oncologist 3: 446 451, 1998.

20. Siddiqui MA and Wellington K. Palifermin: in myelotoxic therapy induced oral mucositis. Drugs 65: 2139-2149, 2005.

21. Porta C, Moroni M, Nastasi G. Allopurinol mouthwashes in the treatment of 5 fluorouracil induced stomatitis. Am J Clin Oncol 17: $246247,1994$.

22. Dodd MJ, Dibble SL, Miaskowski C, et al. Randomized clinical trial of the effectiveness of 3 commonly used mouthwashes to treat chemotherapy induced mucositis. Oral Surg Oral Med Oral Pathol Oral Radiol Endod 90: 39-47, 2000.

23. Barber C, Powell R, Ellis A and Hewett J. Comparing pain control and ability to eat and drink with standard therapy vs. Gelclair: a preliminary, double centre, randomised controlled trial on patients with radiotherapy induced oral mucositis. Support Care Cancer 15: 427-440, 2007.

24. Matsuoka H, Mizushima $Y$, Kawano M, at al. Clinical availability of the herbal medicine, SYOUSAIKOTOU, as a gargling agent for prevention and treatment of chemotherapy-induced stomatitis. Gan To Kagaku Ryoho 31: 2017-220, 2004

25. Zhu H, Zhang J. Treatment of stomatological complications in 31 cases of acute leukemia with Chinese herbal drugs. J Tradit Chin Med 13: 253-256,1993.
26. Braga FT, Santos AC, Bueno PC, et all. Use of Chamomilla recutita in the Prevention and Treatment of oral mukozitis in patients undergoing hematopoietic stem cell transplantation: A randomized, controlled, phase II clinical trail. Cancer Nurs 38 322-329, 2015

27. Abdulrhman M, Elbarbary NS, Ahmed Amin D, Saeid Ebrahim R. Honey and a mixture of honey, beeswax, and olive oil-propolis extract in treatment of chemotherapy-induced oral mucositis: a randomized controlled pilot study. Pediatr Hematol Oncol 29: 285-292, 2012

28. Turgut M, Tutkun F, Celebi N, et al. Topical Ankaferd Bloodstopper in the Management of Critical Bleedings due to Hemorrhagic Diathesis. UHOD 21: 160-165, 2011.

29. Patiroglu T, Sahin NG, Unal E, et al. Efficacy of Ankaferd Blood Stopper in prophylaxis and treatment of oral mucositis in pediatric malignancies: a pilot study. World Federation of Hemophilia. World Congress; Melbourne, May 11-15, 2014: 138.

\section{Correspondence}

Dr. Memis Hilmi ATAY

Ondokuz Mayıs Üniversitesi l̇ç Hastalıkları Anabilim Dalı Hematoloji Bilim Dalı

SAMSUN / TURKEY

Tel: $(+90-530) 4681559$

Fax: (+90-362) 4576091

e-mail: dr.atay@mynet.com 